\title{
The Traditional Engineer vs. The Innovative Engineeer
}

\section{Dr. Daniel Michael Ferguson, Purdue University, West Lafayette}

Daniel M. Ferguson is the recipient of three NSF awards supporting research in engineering education. Prior to coming to Purdue he was Assistant Professor of Entrepreneurship at Ohio Northern University and Associate Director of the Inter-professional Studies Program and Senior Lecturer at Illinois Institute of Technology. His research interests include engineering innovativeness, entrepreneurial engineering, teamwork, and mindset changes and learning strategies of both engineering students and practicing engineers. Prior to his University assignments he was the Founder and CEO of The EDI Group, Ltd. and The EDI Group Canada, Ltd, independent professional services companies specializing in B2B electronic commerce and electronic data interchange. The EDI Group companies conducted syndicated market research, offered educational seminars and conferences and published The Journal of Electronic Commerce. He was also a Vice President at the First National Bank of Chicago, where he founded and managed the bank's market leading professional Cash Management Consulting Group, initiated the bank's non-credit service product management organization and profit center profitability programs and was instrumental in the breakthrough EDI/EFT payment system implemented by General Motors. Dr. Ferguson is a graduate of Notre Dame, Stanford and Purdue Universities and a member of Tau Beta Pi.

\section{Dr. Senay Purzer, Purdue University, West Lafayette}

Şenay Purzer an Assistant Professor in the School of Engineering Education at Purdue University. In 2011, she received a NSF CAREER award, which examines how engineering students approach innovation. She is also a NAE/CASEE New Faculty Fellow. Purzer conducts research on aspects of design education such as innovativeness and information literacy.

\section{Dr. Matthew W. Ohland, Purdue University and Central Queensland University}

Matthew W. Ohland is Professor of Engineering Education at Purdue University and a Professorial Research Fellow at Central Queensland University. He has degrees from Swarthmore College, Rensselaer Polytechnic Institute, and the University of Florida. His research on the longitudinal study of engineering students, team assignment, peer evaluation, and active and collaborative teaching methods has been supported by over $\$ 12.8$ million from the National Science Foundation and the Sloan Foundation and his team received Best Paper awards from the Journal of Engineering Education in 2008 and 2011 and from the IEEE Transactions on Education in 2011. Dr. Ohland is past Chair of ASEE's Educational Research and Methods division and a member the Board of Governors of the IEEE Education Society. He was the 2002-2006 President of Tau Beta Pi.

\section{Dr. Kathryn Jablokow, Pennsylvania State University}

Dr. Kathryn Jablokow is an Associate Professor of Mechanical Engineering and Engineering Design at Penn State University. A graduate of Ohio State University (Ph.D., Electrical Engineering), Dr. Jablokow's teaching and research interests include problem solving, invention, and creativity in science and engineering, as well as robotics and computational dynamics. In addition to her membership in ASEE, she is a Senior Member of IEEE and a Fellow of ASME. Dr. Jablokow is the architect of a unique 4-course module focused on creativity and problem solving leadership and is currently developing a new methodology for cognition-based design. She is one of three instructors for Penn State's Massive Open Online Course (MOOC) on Creativity, Innovation, and Change, and she is the founding director of the Problem Solving Research Group, whose 50+ collaborating members include faculty and students from several universities, as well as industrial representatives, military leaders, and corporate consultants. 


\title{
The Traditional Engineer vs. The Innovative Engineer
}

\begin{abstract}
Business and political leaders in the United States feel that we, as a society, do not understand that new global competition can match and even outpace us on innovation. The purpose of this paper is to provide a description of the traditional or non-innovative engineer as seen from the eyes of the innovative engineer. Traditional engineers or non-innovative engineers are engineers who are the backbone of any company that relies on technology-meaning all $21^{\text {st }}$ century companies. Understanding traditional or non-innovative engineers, given that they are seen as the opposite of innovative engineers, will help us identify the innovative engineer, the hero of our innovation and societal desires.

Traditional or non-innovative does not mean incompetent but does mean the traits that tend to produce good and even great solutions to problems in known or traditional ways and these engineers are the null set when understanding the innovative engineer. The 53 innovative engineers that we interviewed to identify the traits of innovative engineers clearly described the traditional engineer as a way to explain the opposite, the characteristics of an innovative engineer.
\end{abstract}

Our interview based study focused on the research question: "What are the characteristics or knowledge, skills, and attributes that enable or inhibit engineers from translating their creative ideas into innovations that benefit society?" This study was set in an interpretivist framework and we developed a co-constructed description of engineering innovativeness or the lack thereof using 
a grounded theory analysis approach for integrated data collection and analysis. Traditional or non-innovative engineers were described by engineering innovators as people who do not challenge the status quo and are not collaborators. Traditional or non-innovative engineers are engineers who minimize risk, think short-term and focus on a narrow domain of knowledge or expertise.

\section{Introduction}

Innovation in all aspects of modern life is seen as a socioeconomic cure for many of the troubles of modern societies (1-3). "Acting as the translators of new or existing technology into innovations that benefit society (4) is the Olympic torch that engineers are expected to carry" (58). The goal of this study was to identify the unique characteristics of engineers that enable them to produce or inhibit them from producing the innovations that U.S. society so urgently desires. We define these characteristics of engineers that enable or inhibit them from creating innovations as engineering innovativeness or non-innnovativeness.

Study participants defined an innovation as:

"Simply put, it's a new way of doing things. It's breaking tradition and taking a new approach to solving an old problem. I think an innovation is actually only truly innovative if it is delivered to the world and widely adopted, and enjoyably used." Riley

"In my mind innovation is recognizing a need, or a gap, or a circumstance that could be better and then bringing to bear new ways of putting things together, [things] that usually exist, to be able to meet that need, or that gap. " Richard 
Traditional or non-innovative engineers were profiled by engineering innovators as the source of many of the barriers that they had to overcome in developing an innovation. The exploration of traditional or non-innovative engineers as counter points to innovative engineers is a less researched phenomenon but is of particular interest because it is possible to learn from opposites as well as positive examples (9). We believe that knowing or demonstrating innovative traits to grow in engineers is useful to engineers, engineering managers and engineering teachers as is knowing what not to encourage. Demonstrating how not to behave or think is also a well proven teaching technique. And the other side of the coin is that the skills of the traditional or noninnovative engineers can be critical to an effective engineering team. Not only are traditional or non-innovative engineers competent in their work, they are often essential to the successful functioning of a team or company as Ryan explains:

Interviewer: "If you had to hire five engineers would they all be innovative engineers?" Respondent: "No. [some companies] have all the jewels [innovative engineers], but they can't put jewelry together. You need some engineers to do what they're told; and do it well.

But, five innovative guys? All you'd have are these great ideas. You've got to have a shared direction where people will adopt the idea that may not necessarily have come from their mouth and then work together to make it happen. And so I'd rather have one [innovative engineer] than five. I need people that do a lot of different things. Sometimes just making sure that the 100 parts are in that box and a 101 are in that box. But, you don't want everyone having great new ideas to do everything." Ryan 


\section{Background}

There is a paucity of published research on the characteristics of traditional or non-innovative engineers as counter points for innovative engineers. However, a grounded theory interviewbased study with 117 new product development staff in 17 innovative and non-innovative companies found similarities in the behavior of what they judged as non-innovative companies. Innovative in this study of innovative and non-innovative companies was measured by whether the interviewees in the companies felt their companies were innovative and whether the new products of the company were judged to be innovative or, for example, copies of competitor products. The non-innovative behavior identified in the study was described as: “non-innovative organizations restrict [innovative behavior] by framing knowledge as separate, bounded subsets of operations, and defining their links in terms of the optimization of ongoing operations. [They] limited new knowledge to that which improves existing operations; [or] confirms or ratifies current operations." (10)

Dyer et al. also commented on non-innovative behavior of individuals they compared to innovators as finding non-innovators weaker in associating skills, experimenting skills, networking skills, observing skills, and questioning skills as compared to innovators (11). Other research studies have examined the presence or absence of competencies or design skills of specific types of engineers with comparable findings to the descriptions by engineering innovators of the non-innovative engineer $(12,13)$. 


\section{Study Methodology}

This study of engineering innovativeness was set in an interpretivist framework (14) with the purpose of developing a co-constructed description of the critical characteristics of innovative engineers and traditional or non-innovative engineers. The construction of engineering innovativeness was obtained by conducting, recording, and analyzing interviews with 53 experienced and recognized engineering innovators who described the behavior of engineers who were innovative or non-innovative. Demographics of a sample of 20 of these 53 engineering innovators are shown in Table 1. This sample is representative of the entire constructed population of 53 engineering innovators.

Table 1 Demographics of Engineering Innovator Study Sample

\begin{tabular}{|c|c|c|c|c|c|c|c|}
\hline Pseudonym & $\begin{array}{l}\text { Type of } \\
\text { Exper- } \\
\text { ience }\end{array}$ & $\begin{array}{l}\text { Type of } \\
\text { Exper- } \\
\text { ience }\end{array}$ & \begin{tabular}{|l} 
Type of \\
Exper- \\
ience
\end{tabular} & Gender & $\begin{array}{l}\text { Years of Inno- } \\
\text { vation Exper- } \\
\text { ience }\end{array}$ & $\begin{array}{l}* * * \text { Formal } \\
\text { Education }\end{array}$ & $\begin{array}{l}\text { Types of } \\
\text { Innovation } \\
\text { Recognition }\end{array}$ \\
\hline Coding & *Corp & *Acad & *Entre & & & & $* * \mathrm{P}, * * \mathrm{~A}, * * \mathrm{IR}$ \\
\hline Ted & Corp & & & M & $30-40$ & $\begin{array}{l}\text { Chemistry, } \\
\text { Chem Eng }\end{array}$ & $\begin{array}{l}* * \mathrm{P}, * * \mathrm{~A}, \\
* * \mathrm{IR}\end{array}$ \\
\hline Carol & Corp & & Entre & $\mathrm{F}$ & $30-40$ & Chem Eng & $* * \mathrm{~A}, * * \mathrm{IR}$ \\
\hline Ian & Corp & Acad & Entre & $\mathrm{M}$ & $30-40$ & ECE & $\begin{array}{l}* * \mathrm{P}, * * \mathrm{~A}, \\
* * \mathrm{IR}\end{array}$ \\
\hline Riley & Corp & & Entre & $\mathrm{M}$ & $30-40$ & Comp Sc & $* * \mathrm{~A}, * * \mathrm{IR}$ \\
\hline Ryan & & Acad & Entre & $\mathrm{M}$ & $20-30$ & $\mathrm{ME}$ & $* * \mathrm{~A}, * * \mathrm{IR}$ \\
\hline Toni & Corp & & & $\mathrm{M}$ & $30-40$ & $\mathrm{ME}$ & $* * \mathrm{P}, * * \mathrm{IR}$ \\
\hline Dana & Corp & Acad & Entre & $\mathrm{F}$ & $30-40$ & \begin{tabular}{|c|} 
Chem Eng, \\
Bio, Bus, \\
SS \\
\end{tabular} & **A,**IR \\
\hline Richard & Corp & Acad & & $\mathrm{M}$ & $40-50$ & $\mathrm{ME}$ & $\begin{array}{l}* * \mathrm{P}, * * \mathrm{~A}, \\
* * \mathrm{IR}\end{array}$ \\
\hline Tarik & Corp & & Entre & $\mathrm{M}$ & $40-50$ & TRIZ & $* * \mathrm{~A}, * * \mathrm{IR}$ \\
\hline Peter & Corp & & & M & $30-40$ & Arch Eng & $* * \mathrm{P}, * * \mathrm{~A}, * * \mathrm{IR}$ \\
\hline Bruno & Corp & Acad & & $\mathrm{M}$ & $40-50$ & Mat Eng & $\begin{array}{l}* * \mathrm{P}, * * \mathrm{~A}, \\
* * \mathrm{IR}\end{array}$ \\
\hline Doris & Corp & & & $\mathrm{F}$ & $20-30$ & Anal Chem & $* * \mathrm{~A}, * * \mathrm{IR}$ \\
\hline Aubrey & Corp & & & $\mathrm{F}$ & $30-40$ & Bio Eng & $* * \mathrm{P}, * * \mathrm{~A}, * * \mathrm{IR}$ \\
\hline David & Corp & & Entre & $\mathrm{M}$ & $30-40$ & $\mathrm{ME}$ & $* * \mathrm{~A}, * * \mathrm{IR}$ \\
\hline Pierre & Corp & & & $\mathrm{M}$ & $40-50$ & $\mathrm{ME}$ & $\begin{array}{c}* * \mathrm{P}, * * \mathrm{~A}, \\
* * \mathrm{IR}\end{array}$ \\
\hline Edward & Corp & Acad & & $\mathrm{M}$ & $20-30$ & Aero Eng & $* * \mathrm{~A}, * * \mathrm{IR}$ \\
\hline
\end{tabular}




\begin{tabular}{|l|l|l|l|c|c|c|c|}
\hline Joseph & Corp & Acad & Entre & M & $20-30$ & MD & $\begin{array}{c}* * \mathrm{P}, * * \mathrm{~A}, \\
* * \mathrm{IR}\end{array}$ \\
\hline Greg & Corp & Acad & & $\mathrm{M}$ & $30-40$ & $\mathrm{ECE}$ & $\begin{array}{c}* * \mathrm{P}, * * \mathrm{~A}, \\
* * \mathrm{IR}\end{array}$ \\
\hline Jordan & & Acad & Entre & $\mathrm{M}$ & $20-30$ & Chem Eng & $\begin{array}{c}* * \mathrm{P}, * * \mathrm{~A}, \\
* * \mathrm{IR}\end{array}$ \\
\hline Nathan & Corp & & & $\mathrm{M}$ & $30-40$ & $\mathrm{ME}$ & \begin{tabular}{c}
$* * \mathrm{~A}, * * \mathrm{IR}$ \\
\hline
\end{tabular} \\
\hline
\end{tabular}

$\underline{\text { Legend }}$

$*$ Corp $=$ Corporate,$*$ Acad $=$ Academic,$*$ Entre $=$ Entrepreneurial

$* * \mathrm{P}=$ listed on greater than 5 Patents,,$* * \mathrm{~A}=$ Innovation Awards, $* * \mathrm{IR}=$ Innovation

Responsibility

*** Aero Eng = Aerospace Engineering, Anal Chem = Analytical Chemistry, Arch Eng = Architectural Engineering, Bio Eng = Biological Engineering, Bus = Business, Chem =

Chemistry, Chem Eng = Chemical Engineering, Comp Sc = Computer Science, ECE = Electrical and Computer Engineering, Mat Eng = Materials Engineering, MD = Medical Doctor, $\mathrm{ME}=$ Mechanical Engineering, SS = Six Sigma, TRIZ = Russian Innovation Analysis Process

An exploratory interview-based pilot study (15) of engineering innovativeness was conducted in the summer and fall of 2011 with eight engineering innovators, averaging over thirty years' innovation and engineering experience. The purpose of the pilot study was to inform the process of conducting the full study on engineering innovativeness (16). Results from the exploratory study assisted in the design of the second larger study of 45 engineering innovators and confirmed that the characteristics of innovative and non-innovative behavior in engineers can be identified.

Data collection for the $2^{\text {nd }}$ full study started with open-ended semi-structured interviews of engineering innovators in the summer of $2012(15,17)$. A purposeful criterion sample of engineering innovator participants (15) was identified and recruited by contacting engineering professionals in multiple disciplines and locations to act as connectors to engineering innovators (18). Additional engineering innovators were then recruited using a criterion-based snowball 
approach expanding from the professional networks of engineering connectors and engineering innovator interviewees $(15,18)$.

A grounded theory analysis approach for integrated data collection and analysis was used to construct and test a model of the critical factors of engineering innovativeness and noninnovativeness across the interviewee-defined stages of the innovation process $(15,19)$. Memos were written during coding to inform the model construction (19). After construction of a codebook and coding reliability testing with research collaborators, interviews were coded until theoretical and categorical saturation was achieved at 15 interviews (15, 19). Additional interview sampling and coding of 5 interviews was done after categorical and theoretical saturation was reached to provide confirmation of analysis results, increase sample size and expand the data available for report writing (15).

This study was executed as a qualitative study because we were seeking a detailed understanding of the phenomenon of engineering innovativeness or non-innovativeness by talking with individuals who are engineering innovators in the 'naturalistic settings in which they innovate' $(17,20)$. The confusion surrounding the 'central phenomenon' of innovativeness in engineers makes a qualitative study approach an appropriate research method $(8,17,20)$ because we are addressing the general research question, "What is or is not engineering innovativeness?" to engineers who have successfully experienced the innovation process and demonstrated that they are engineering innovators. We are also extending the understandings that emerged from our engineering innovativeness pilot study $(9,17)$. 
This study was conducted with a grounded theory analysis approach because the results of this study were generated inductively from interviews of experienced and recognized engineering innovators rather than from experiments in a laboratory or from data gathered from inexperienced or non-innovative engineers $(15,16)$. The models of engineering innovativeness and non-innovativeness that were developed during this study come from the data collected or 'grounded' in the interviews and descriptions of engineering innovators and non-innovators provided by engineering innovators, not from any experimentally constructed data sources (15). Study participants described the characteristics of non-innovative engineers as they described the characteristics of innovative engineers and describing both innovative and non-innovative behavior of engineers was a common approach to sharing insights and reflecting on our interview questions.

Grounded theory was an appropriate methodology due to the confusion and conflicting theories that surround the definition of innovativeness and therefore engineering innovativeness or the lack thereof (8). After collecting and analyzing data from expert engineering innovators the models of engineering innovativeness and non-innovativeness were constructed by interpreting the actual engineering innovation experiences that the study participants created themselves and observed in other engineering innovators and non-innovators. By sampling only engineering innovators the study findings were differentiated by the uniqueness of the data; i.e., the study data describes the real innovation experiences of innovative engineers, and it is from this grounding in real engineering innovator experiences that the models of engineering innovativeness and non-innovativeness were built (19). All participant quotes shown in this paper are reported using pseudonyms. 


\section{Findings}

The traditional or non-innovative engineers was described by the study participants as they reflected on the characteristics of the innovative engineer. Traditional or non-innovative engineers were described by engineering innovators as: not collaborators and people who don't challenge the status quo. They were seen as someone who minimizes risk, is not persistent in generating new approaches to problem solving, and thinks short term. Traditional or noninnovative engineers focus on a narrow domain of knowledge or expertise rather than a broader more diverse knowledge and skill base which would equip them to generate and move an innovation all the way to implementation. The traditional or non-innovative engineers was also seen as someone who solved today's problems. Staying within the system, using established solutions and not collaborating with others were described as hallmarks of the traditional or noninnovative engineers but also were frequently recognized as valuable or even essential contributions to the firm or organization:

"I can describe people that don't [innovate]. They tend to stay within the system, and stay within the rules. They stick to their objectives and to an extent that they oftentimes can't achieve their objectives because they're not networking." Aubrey

"In my perspective there [are] a lot of people that are just looking for established solutions. They just want to execute what has been proven to work before. And that's fine for most things." Toni

Minimizing risk is also a behavior tagged onto the traditional or non-innovative engineers and it is their preferred way of approaching problems in that it is their preferred mindset: 
"I think very few people actually tolerate mistakes and failures. I think most people see it as a setback versus using [mistakes and failures] as a jumping pad to leap to what could be." Carol

"Some people you can offer them 10 different ideas in 10 different meetings, and nine out of ten, or maybe like nine and a half out of ten times the answer's just going to be, "No." Here's a reason why we shouldn't do it. Here's another reason why. Did you think about that?" You know, even things that you can't think of a single reason why [we] can't do it; they can think of a reason. It's because they're very good at screening for the risks. And, they don't want deviations from [a] process that has been used before. If something is to be done, they're really going to say it has been done that way before and that makes it okay to do it [that way] again. So there's kind of that mindset." Ian

Traditional or non-innovative engineers give up more quickly on generating new solutions as a risk reducing strategy than innovative engineers. They don't have as much tenacity as an innovative engineer to stay a longer time with an innovation and work less hard to overcome opposition or barriers to an innovations' development or implementation:

“And someone says [non-innovators] 'Oh, that's a great idea but it's too complex and too costly.' They just shut that person down because [non-innovators] don't have the tenacity to say 'I'm going to go solve the complexity and I'm going to go solve the cost problem.' So diligence is a characteristic of [innovators], working through problem 
after problem. Tenacity works [as a descriptor] but it's that follow-through [that makes the difference], realizing that a problem's not a showstopper. It's just another problem." Tarik

Thinking longer term is a skill of the innovative engineer and its' absence marks the traditional or non-innovative engineers:

"[Non-innovators] are the ones that cannot get out of the short-term, or say this is the way we've always done things. I see that a lot ... whether they don't see [the value of the innovation], or they think it's too much work. Gee, if I've got to develop a whole supply chain, that's too much work." Ted

A need for a diverse knowledge base across multiple domains is highlighted when considering its' absence in a traditional or non-innovative engineers:

"I think if someone is locked into one area of science and that's all they learn. I think that's a detriment. They need the balance. They need the understanding. If it's a mechanical problem it doesn't mean it's a mechanical solution. If they can't look outside their mechanical domain of knowledge then how are they going to find the solution?" Tarik

Traditional or non-innovative engineers are also seen as preferring to stay within their area of technical expertise and not developing a broader perspective and this is seen as a major impediment to participating as an innovative engineer in the later stages of the innovation process. Alternatively, for a traditional or non-innovative engineers, becoming an expert in a narrower 
technical domain can mean solving standard problems quicker and coming up with more reliable and cost effective solutions within their knowledge base.

"If you're going to ultimately convert an innovation into a commercial endeavor you've got to approach it in a way of solving multi-functional, multi-department kinds of issues. And that can be an inhibitor for a lot of people who are maybe very creative but don't know how to build an innovation that actually will have traction. A small percentage of us maintain a network that is highly diverse. Where a trait that most [engineers] have, 99\% of the world, is we like hanging out with people who are kind of like us. To be a successful innovator and ultimately an entrepreneur, having a [diverse] network of people [is needed]. If I'm a technical person, knowing sales people, knowing marketing people, knowing attorneys, know [ing] financial people, that's not a comfort zone for many technical people. ” David

"[Developing the business proposition] is the hardest [part of the innovation process] from an engineering perspective. And I've seen very few engineers that are really good at it because often the engineers look [at innovation] through an engineering lens. I truly believe that a really good engineer that's innovative needs to have market awareness and domain expertise. They need to be business savvy. They need to have the ability to look at the invention or idea through the lens of a business proposition. It's not just about how strong or how fast or how quick or what it costs. It's about what does it ultimately mean to the end user? What is the business proposition for the company? So the ability to look through a business lens and find a way to create something that not only delivers [value] 
to the end user but balances what the business proposition has to be [describes] a true [engineering innovator]." Carol

Table 2 Definitions of characteristics associated with both innovators and non-innovators

\begin{tabular}{|c|c|c|}
\hline $\begin{array}{l}\text { Characteristic } \\
\text { Name }\end{array}$ & $\begin{array}{l}\text { Innovative Characteristic } \\
\text { Definition* }\end{array}$ & $\begin{array}{l}\text { Characteristic Description Quotes Sourced from } \\
\text { Interviews with } 53 \text { Engineering Innovators }\end{array}$ \\
\hline Challenger & $\begin{array}{l}\text { Questions or disputes the } \\
\text { current way of doing } \\
\text { something. }\end{array}$ & $\begin{array}{l}\text { "Always unsatisfied with the way things are, } \\
\text { doesn't follow rules, not bound by rules." } \\
\text { "Highly innovative people are the ones that } \\
\text { challenge authority." }\end{array}$ \\
\hline Collaborator & $\begin{array}{l}\text { Works with another } \\
\text { person or group in order } \\
\text { to achieve or do } \\
\text { something. }\end{array}$ & $\begin{array}{l}. " \text { "You have to go out and find the people to } \\
\text { work with." } \\
\text { "You've got to be willing to find these people, } \\
\text { make the connections, and bring these different } \\
\text { ideas in. The network supports you, they give you } \\
\text { ideas." }\end{array}$ \\
\hline Persistent & $\begin{array}{l}\text { Continuing to do } \\
\text { something even though it } \\
\text { is difficult or other people } \\
\text { want you to stop: } \\
\text { continuing beyond the } \\
\text { usual, expected, or normal } \\
\text { time }\end{array}$ & $\begin{array}{l}\text { "[Innovators] don't give up easy." } \\
\text { "[Innovators] will continue to pursue (the idea) } \\
\text { even if someone says It's not what it should be. It } \\
\text { doesn't make sense. They constantly exhibit that } \\
\text { courage and resilience and persistence regardless } \\
\text { of the barriers in front of them." }\end{array}$ \\
\hline Risk Taker & $\begin{array}{l}\text { Accepts the possibility } \\
\text { that something bad or } \\
\text { unpleasant (such as an } \\
\text { injury or a loss) will } \\
\text { happen }\end{array}$ & $\begin{array}{l}\text { "Innovators in my mind fail often early so they } \\
\text { can succeed sooner." } \\
\text { "They're not afraid of failure in terms of trying } \\
\text { something and seeing if it works; or if part of it } \\
\text { works, or if a portion of it works. And then } \\
\text { they'll try some other thing. But they're not } \\
\text { afraid to learn from something that didn't quite } \\
\text { work as they thought but part of it did work." }\end{array}$ \\
\hline Visionary & $\begin{array}{l}\text { Has or shows clear ideas } \\
\text { about what should happen } \\
\text { or be done in the future } \\
\text { Thinks long term }\end{array}$ & $\begin{array}{l}\text { "You've got to have a long term focus too, some } \\
\text { ability to think long-term rather than short-term." } \\
\text { "They're forward thinking, they live in the future, } \\
\text { their heads are in the future." }\end{array}$ \\
\hline
\end{tabular}

*Sourced from Marrion-Webster online dictionary 


\section{Role of the Non-innovative vs. Innovative Engineers}

The definitions of five characteristics identified for traditional or non-innovative engineers vs. innovator engineer were intuitively developed and are shown in Table 2 . These five characteristics were: Challenger, Collaborator, Persistent, Risk Taker and Visionary. They are described for the innovative engineer and their opposite is the characteristic described for the traditional engineer. They are also the major differentiating characteristics cited as defining the behavior of traditional engineers.

Summarizing the descriptions of traditional engineers they don't challenge the status quo and are not collaborators. They minimize risk, are not persistent in seeking new ways to solve problems, think short term and focus on a narrow domain of knowledge or expertise rather than a broader more diverse knowledge and skill base. This comparison of innovators and non-innovators from the eyes of the engineering innovator is revealing in describing their biases and also the tension that exists in a firm between innovating new processes or products versus more direct and perhaps timely problem solving. Figure 1 restates this summary in a comparison format:
An innovative engineer:
A non-innovative: engineer:
is a collaborator
focuses narrowly on their area of expertise
is a risk taker
minimizes risk for the firm
has a long term focus
has a short term focus on problem solving
is persistent
is not persistent in seeking new ways when solutions exist
challenges rules
sticks to rules they know will work

Figure 1 Innovative vs. Non-Innovative Engineer 
The innovative engineer invokes a caricature of the traditional or non-innovative engineers when they describe the traditional or non-innovative engineers as risk averse, easily thwarted in seeking new solutions, and narrowly focused on their area of expertise. They agree traditional or non-innovative engineers are competent and hard-working but believe they don't think long term and complain that they don't develop a network or collaborate in ways that support the development of innovations. Or in other words they aren't like me and to quote several interviewees 'most engineers aren't innovators'.

As Ryan pointed out earlier traditional or non-innovative engineers are also critical to the functioning of teams and companies and the caricature above in Figure 1 does not do them justice. Accepting that -innovative engineers are a smaller minority of all engineers, most engineers are gainfully employed and competent, there must be a large need for solving problems within known parameters and minimizing elements of the problem solution like cost and risk.

\section{Conclusion}

The major value in understanding the traits, preferences and skills of traditional or noninnovative engineers lies in two insights. One, when the problem is a familiar and manageable one, selecting a traditional or non-innovative engineers to address the problem is the answer and a good choice. Getting the problem solved effectively and quickly with less risk is a good decision. But two, when the problem is not familiar, when there are no ready solutions at hand, and when you are not even sure of the definition of the problem, the non-innovative engineer or someone who struggles to be innovative is not necessarily a good choice. The innovative engineer is willing to break rules, take risk, challenge authority, think longer term and likely to persist until they find a new way to solve the problem. They are also going to collaborate with 
others outside of their knowledge base so that the potential solutions they acquire are not bounded by what they know or able to do. Seeking solutions outside your knowledge base may not be something a traditional or non-innovative engineers wants to do but it an essential practice for the innovative engineer. Therefore, fitting the type of innovative engineer to the nature of the problem is an essential task if solving the problem and being more successful in serving your customers is an organizational goal.

\section{Next Steps}

There are several opportunities to extend this research in engineering innovativeness and noninnovativeness by:

- Exploring the relationships between engineering traditional or non-innovative engineer characteristics to identify dominating and controlling characteristics that contribute most significantly to an engineer's non-innovativeness.

- Developing a better understanding of the strengths and weaknesses of the traditional or noninnovative engineers in comparison to the innovative engineer in order to identify the strategies for mixing the strengths of the traditional or non-innovative engineers with innovative engineers in the teams of engineers that are usually required to analyze and resolve engineering problems.

- Compiling a more comprehensive list of the characteristics of traditional or non-innovative engineers to assist in identifying and enabling or inhibiting these characteristics as early as possible in the training and growth of a student or professional engineer thereby potentially improving their innovativeness or traditional engineering skills. 
- Analyzing the different combinations of innovative or non-innovative characteristics to identify relationships among engineering characteristics and combinations of those characteristics that have naturally arisen in innovative or non-innovative engineers. These characteristic combinations are possibly the dominant evolutionary packages of engineering innovator characteristics to correct, discourage and not support if you want an innovative engineer. Conversely they may be exactly the combinations of characteristics that should be supported or encouraged to grow if your goal is to have or develop traditional or noninnovative engineers.

\section{Acknowledgment}

This paper is based upon work supported by the National Science Foundation's Engineering Education Program under Grants \#1264769 and \#1264901. Any opinions, findings, conclusions, or recommendations expressed here are those of the authors and do not necessarily reflect the views of the National Science Foundation.

\section{Bibliography}

1. National Academy of Sciences, National Academy of Engineering, Institute of Medicine. Rising Above The Gathering Storm: Energizing and Employing America for A Brighter Economic Future. Technology CoPitGEot ${ }^{\mathrm{s} C A A f A S a}$, editor. Washington, D.C.: National Academy of Sciences; 2007.

2. $\quad$ Kelley T, Littman J. The Art of Innovation. New York: Doubleday; 2001.

3. Frieman M. The World Is Flat:A Brief History of the Twenty-first Century. New York: Farrar, Straus \& Giroux 2005.

4. National Academy of Engineering. The Engineer of 2020. Washington D.C.: National Academy of Sciences; 2004.

5. Castillo S. Minutes of the Directorate for Engineering Advisory Committee Meeting. Arlington, VA: National Science Foundation2010 Oct. 20-21, 2010.

6. Jablokow K, Purzer S, Ferguson D, Ohland M. Collaborative Research: Identifying and Assessing Key Factors of Engineering Innovativeness. 2012.

7. Crawley EFSL. Rethinking engineering education the CDIO approach. New York: Springer; 2007. 8. Ferguson D, Ohland MW. What is Engineering Innovativeness? International Journal of Engineering Education. 2012;28(2).

9. Flanagan JC. The critical incident technique. Psychological bulletin. 1954;51(4).

10. Dougherty D, Borrelli L, Munir K, O’Sullivan A. Systems of organizational sensemaking for sustained product innovation. Journal of Engineering and Technology Management. 2000;17:321-55. 
11. Dyer J, Gregersen H, Christensen CM. The Innovator's DNA: Mastering the Five Skills of Disruptive Innovators. Boston MA: Harvard Business Review Press; 2011.

12. Robinson MA, Sparrow PR, Clegg C, Birdi K. Design engineering competencies: future requirements and predicted changes in the forthcoming decade Design Studies. 2005 26:123-53.

13. Turley R, Bieman JM. Competencies of Exceptional and Nonexceptional Software Engineers. Systems Software. 1995;28:19-38.

14. Cohen D, Crabtree B. Qualitative Research Guidelines Project. Princeton, NJ 08543: Robert Wood Johnson Foundation; 2008. Available from: http://www.qualres.org/HomeInte-3516.html

15. Patton MQ. Qualitative Research and Evaluation Methods. Thousand Oaks, CA: Sage Publications; 2002.

16. Ferguson DM, Cawthorne JC, Ahn B, Ohland M, editors. Engineering innovativeness. ASEE 2012

International Conference on Engineering Education; 2012; San Antonio, Texas American Society of Engineering Education.

17. Creswell JW. Educational Research: Planning, Conducting, and Evaluating Quantitative and Qualitative Research. Upper Saddle River, NJ: Pearson; 2008.

18. Gladwell M. The Tipping Point: How Little Things Can Make a Big Difference. ISBN 0-316-31696-2 ed: Little Brown; 2000.

19. Charmaz K. Constructing Grounded Theory: A practical Guide Through Qualitative Analysis. Los Angelos, CA: Sage Publications, Inc.; 2006.

20. Lincoln YS, Guba EG. Naturalistic Inquiry. Newberry California: Sage Publications, Inc.; 1985. 